\title{
The Impact of Corporate Characteristics and Corporate Governance on Corporate Social and Environmental Disclosure: A Literature Review
}

\author{
Omer M Elsakit $^{1}$ \& Andrew C Worthington ${ }^{1}$ \\ ${ }^{1}$ Department of Accounting, Finance and Economics, Griffith Business School, Griffith University, Australia \\ Correspondence: Omer M Elsakit, Department of Accounting, Finance and Economics, Griffith Business School, \\ Griffith University, Australia. Tel: 614-3428-4241. E-mail: O.elsakit@griffith.edu.au
}

Received: June 24, 2014

Accepted: June 8, 2014

Online Published: August 22, 2014

doi:10.5539/ijbm.v9n9p1

URL: http://dx.doi.org/10.5539/ijbm.v9n9p1

\begin{abstract}
This paper aims at investigating the impact of corporate characteristics and corporate governance upon the level and extent of corporate social and environmental disclosure, with special reference to the case of banks. A desk-based research method has been used, by discussing and criticizing, where appropriate, the results of some related studies. The paper confirms the importance of these factors in determining the level and extent of such disclosure.
\end{abstract}

Keywords: corporate characteristics, corporate governance, social and environmental disclosure

\section{Introduction}

There are some factors which have been argued by researchers to be having a role in determining the disclosure level of social and environmental information related to firms' activities. Hossain and Reaz (2007) argued that one of the most three important issues encounters researchers, in disclosure-related studies, is identifying and understanding the factors influencing managers' decisions regarding disclosure issue, and how such understanding can be beneficial in predicting disclosure levels, and thus enhancing the quality of firms' reports in terms of non-financial information. These factors can be broken down into three groups: general contextual factors; corporate characteristics; and internal contextual factors (Adams, 2002). This paper discusses the latter two factors, with corporate governance representing the internal contextual factors.

\section{Corporate Characteristics}

Many corporate characteristics have been believed to be explanatory variables for the status of CSED provided by corporations. These characteristics include, and not limited to, profitability; size, ownership, and listing on stock exchange.

\subsection{Profitability}

For several reasons, profitability is found to be a reason for disclosing more information pertaining to the effects of corporation's activity on society and environment. Hossain and Hammami (2009) considered political costs, financial performance justification, and self-interest of managers as explanatory factors for profitability being a motive for disclosing more social and environmental information. A corporation management might feel that it has to prove that its profits were not on expense of its social and environmental performance, that is, it did not cause any harm to society or environment while achieving its profits. In addition to this possible explanation, costs expected to be imposed- in case of achieving high levels of profitability- by some external groups such as trade unions (in form of calling for increasing workers' wages for example) might be an impetus for emphasizing the social and environmental role of the firm (employees issues in the case of the example). Self-interest, such as keeping their positions, can be also taken into account by managers in their decisions with respect to social and environmental disclosure, since enhanced social image has increasingly become preferred by information users. Haniffa and Cooke (2005) justified the action of disclosing social information by corporation's desire to be seen as a positive participant in society development.

In empirical filed, numerous studies have proved the existence of the relation between profitability and social and environmental disclosure, in different contexts in terms of countries and industries. For instance, Cormier 
and Magnan (2003), conducted their study on around 50 French companies operating in seven different sectors. In their study, profitability was found to be a significant determinant of the strategy implemented for environmental reporting. In Sweden, Tagesson et al. (2009) examined social disclosures of 267 Swedish listed firms, operating in various industries. The study findings lend support to the positive association between profitability and the extent and content of social disclosure presented on the firms' websites, as profitable companies can incur the cost of disclosing more social information.

In a different context, developing countries, annual reports of a sample of non-financial firms in Malaysia were analysed by Haniffa and Cooke (2005), in the two years: 1996 and 2002, in order to evaluate the level of social and environmental disclosure made in the annual reports, and its sensitivity to: culture, corporate governance, and some of firm's characteristics (including profitability). One of this study's results is that profitability was found to be a vital factor in relation to promulgating social information by firms.

Considering the case of banks, Hossain and Reaz (2007) mentioned the study of Hossain (unpublished M.Phil. thesis) which was conducted in order to determine the extent of disclosure made by 25 Bangladeshi banks, and testing the relationship between its level and some bank's characteristic. Of the study results, profitability was proved to be an important characteristic in terms of determining the level of disclosure made by banks. Another study, in Bangladesh as well, was carried out by Khan (2010), and focused on social and environmental disclosures made by all private commercial banks, in the year 2007-2008. In this study, it was found that -inter alia- profitability is, statistically, important pertaining to the level of social and environmental disclosures.

In contrast to the results mentioned above, some studies proved the opposite findings. For instance, in different sectors including banks, the sample of the study of Hossain and Hammami (2009) contained 25 firms listed in Doha Securities Market (DSM) in Qatar (representing around 86\% of the firms listed). The annual reports of the year 2007 were considered in examining the determinants of non-compulsory disclosure (including social one), and the association between this kind of disclosure and some firm characteristics was analysed. In contrasting with the previous results, profitability characteristic was found to be insignificant in relation to the determinants of voluntary disclosure. This result confirmed that of another study focused only on banking sector in India, conducted by Chipalkatti (2002), who examined the relationship between the nature and quality of disclosures appeared in annual reports of the year 2000 (made by 17 Indian banks), and market microstructure variables. The study findings indicated that, regarding profitability, no important differences were found in disclosure levels notwithstanding the different profitability levels recorded.

These conflicted results confirmed the claim of some researchers, such as Patten (1991), Mangos and Lewis (1995), and Haniffa and Cooke (2005), that the results regarding the association between profitability and corporate social disclosure is inconclusive. Some possible reasons can be given to justify such conclusion. Haniffa and Cooke (2005) suggested that the freedom and flexibility management has (in conducting, and disclosing information on, social responsibility programs) can be a key reason for the relationship being positive. Moreover, the relationship between size and profitability is expected to make the association between the latter and social disclosure complicated (Mangos \& Lewis, 1995). Based on this, it can be also argued that being affected by so many factors (internally and externally), social and environmental disclosure and its relationship with profitability can be influenced by the overlap of those factors, and the level of its strength.

\subsection{Size}

There is almost a consensus on the existence of a relationship between firm size and the extent of disclosures made for information users. Size is argued to be a significant variable in explaining the disclosure levels. Some authors, such as Cowen et al. (1987) reached the result that size is the most significant explanatory variable of social disclosure. They stated "large companies tend to have greater numbers of social responsibility disclosure" (Cowen et al., 1987, p. 117). By the same token, Singhvi (1971) argued that Small firms are more likely to release inadequate financial information. The researcher provided the following three possible reasons for such case: the high cost of gathering and producing adequate information comparing to large firms; the lack of their managers' awareness regarding the expected benefits of disclosing more information; and the assumption that more disclosure may threaten their performance and competitive position in the market. These reasons are also claimed to be valid in the case of social and environmental disclosure practices, where many researchers found that large firms disclose more social and environmental information than small ones.

Many theories, such as legitimacy and agency theories, are involved in explaining why size is one of the determinants of social and environmental disclosure level, and why there is a positive relationship between the two. Some attributes of the large company can be noted in understanding why it discloses more information. Firstly, since agency costs is assumed to be higher in the case of the large company (Jensen \& Meckling, 1976 
cited by Hossain \& Hammami, 2009, p. 260), managers might use social disclosure as a tool to cut these cost, especially political ones (Farook, Lanis, \& Hassan, 2011; Watts \& Zimmerman, 1978). Secondly, large firms received more attention (Wallace \& Naser, 1995), and this in turn results in a need for justifying the existence of the firm (Farook et al., 2011; Patten, 1991). Thirdly, large firm is more likely to have an economic significance in eyes of different interested groups (Cooke, 1991), thus, is followed by more analysts (Lang \& Lundholm, 1993; McKinnon \& Dalimunthe, 1993), subjected to more scrutiny (Andrew, Gul, Guthrie, \& Teoh, 1989), and thus, needs to disclose more information. Fourthly, availability of money and expertise in large companies enable them to engage in more activities (which likely to have great impacts on society and environment), produce more information on these activities and their implications, and bear the cost of such processes (Ahmed \& Nicholls, 1994; Andrew et al., 1989). Lastly, growth of large firm entails external capital, which is more likely to be obtained in case of availability of high quality information (Wallace \& Naser, 1995).

Empirically, numerous studies have been conducted and proved the positive relationship between firm size and the extent of its disclosure. This association was found in different contexts, developed and developing countries, and in different samples: where banks were not included, included, or represented the whole sample.

Of those studies which did not consider banks' case, the result of Deegan and Gordon's (1996) study revealed that size of Australian firms, operating in environmentally sensitive industries, is positively associated with disclosing environmental information. Cormier and Magnan (2003) also found that large firms are more likely to disclose more environmental information than small ones. This study was an extension of Cormier and Magnan's (1999) study, which considered Canadian case, by using a cost-benefit framework so as to identify factors influencing environmental disclosure made by 33 firms (in three industries, namely: pulp and paper; oil refining and petrochemicals; and steel, metals, and mines) in 212 firm-year observations during the period of 1986-1993. In this study, size was, also, found to be an explanatory factor for environmental disclosure. Large Canadian firms were found producing and releasing more environmental information. Cormier and Magnan (2003, p. 44), in explaining Canadian case, stated "large Canadian firms disclose more than small firms. Since large firms are more visible, they are likely to bear the brunt of the costs resulting from political or lobbying actions". Another support came from Cormier et al. (2011), confirming the result that size is one of the major factors in determining the environmental disclosure. The sample of the study consisted of 137 non-financial Canadian firms with focusing on web disclosure in 2005.

With respect to social and environmental disclosure together, the result, regarding the relationship between size and disclosure level, did not differ in the study of Cormier and Gordon (2001). The researchers analysed social and environmental disclosure made in annual reports of three electric utilities, public and private, in Canada within the period from 1985 to 1996. It was found that firm size affected the amount of social and environmental information released by firms, with largest firm disclosed more than the smallest. The study of, Tagesson et al. (2009), in Sweden, also confirmed the positive relationship between firm size and amount and content of information released regarding the social and environmental effect of firms' activities. In explaining this finding, the authors argued that large firms have a large number of interested people and groups. As a result, there is a great need for producing more social information, and such need can be met by large staff working for those firms. In different context, developing countries, Imam (2000), who examined the annual reports of 40 Bangladeshi companies during the period 1996 and 1997, found- inter alia- that "only large companies (based on market capitalisation and turnover) reported social and environmental matters in their annual reports" (Imam, 2000, p. 139). In Malaysia, Haniffa and Cooke (2005) found also firm size to be a significant element in relation to social disclosure of 139 non- financial corporations.

Even though the previous results were confined to the case of non-financial companies, no differences have been noted when banks were considered along with other companies operating in non-financial sectors. In UK, the study of Clarke and Gibson (1999) considered non-mandatory disclosure regarding environment and society, and revealed that annual reports were found to be used mostly by large companies (including banks) to release information regarding their social and environmental impact. In Italy, Secchi (2006) found that the main producer of social reports were medium and large companies, and were mainly banks. In Portugal, of the hypotheses developed in the study of Branco and Rodrigues (2008), it was expected that a positive relationship will be found between size and social disclosure. The researchers analysed the disclosures made by 49 Portuguese companies in 17 different sectors (including banking sector), in their annual reports of 2003 and firms' websites in August 2004. The results were in the expected direction.

At the global level, the importance of size has been also highlighted. Baskin (2006), in his comparison study, analysed social and environmental disclosures of 1827 corporations (in different sectors including banking) in both developed and developing countries. The results revealed that the level of corporate responsibility reporting, 
published in emerging markets, was higher than the expectations, and this was due to some circumstances, such as: the efforts made by large companies to become globally recognised.

With samples chosen just from the context of developing countries, firm size continued proving itself to be an important element in determining the level of social and environmental disclosure. In Singapore, Eng and Mak (2003) tested the impact of some factors on voluntary disclosure of 158 Singaporean listed firms (financial and non-financial firms) in the year of 1995. It was found that large firms release more voluntary disclosure. In studies including banks in their samples, Andrew et al. (1989) found that the social disclosure made by publicly-listed companies in Malaysia and Singapore, for the year ending December, 1983, was very limited ( just 31 out of 119 firms made such disclosure). Regardless of this result, size was found to be a significant factor, where the attention to social effects of companies' activities was paid by the largest ones. Similarly, the study of Gao (2005), in Hong Kong, confirmed the importance - and positive impact- of company size in determining the amount of social and environmental information disclosed in 154 annual reports of 33 listed companies (operating in three sectors namely: property, banking and utilities) covering the period of $1993-1997$. Other two studies, which used mixed samples (including banks), were conducted in Malaysia and Qatar in the years 2008 and 2009 respectively. The first was conducted by Amran and Devi (2008) and the latter was achieved by Hossain and Hammami (2009). Both studies provided additional support to all studies mentioned, in that firm size is a significant in the topic of social disclosure.

In studies conducted exclusively on banks, the results provides no evidences but the positive relationship between size and the extent of social and environmental disclosure made by banks. Hossain and Reaz (2007), emphasised the significant of bank size in determining the extent of its voluntary disclosure. They stated "Most researchers in this area find a close relationship between these two variables in both developing and developed countries" (Hossain \& Reaz, 2007, p. 278). This relationship was also proved in their study of voluntary disclosures made by 38 listed banks in India. The researchers confirmed the validity of the studies mentioned in their literature review (regarding bank size), such as; the study of Kahl and Belkaoui (1981) who found a positive relationship between bank size and the level of the disclosures made by 70 banks in 18 different countries, and that of Hossain (unpublished M.Phil. thesis) who consider the disclosures of 25 Bangladeshi banks. In India, Chipalkatti (2002) analysed the annual reports of 17 Indian banks, and found- inter alia- that better disclosures are more likely to be produced by large banks, and he justified this finding by the potential pressure of investors and authorities. In the study of Khan (2010), the investigation of annual reports (of the year 2007-2008), published by all private commercial banks in Bangladesh, lend more support for the significance of bank size pertaining to the level of social disclosure.

One last study to be mentioned in this context is that conducted by Branco and Rodrigues (2006). The interesting observation on this study is that, unlike other studies which used different measures as proxies for firm size, such as: assets (M. Branco \& Rodrigues, 2008; Hossain \& Reaz, 2007), number of employees (Amran \& Devi, 2008), turnover (Andrew et al., 1989; Imam, 2000), and sales (Deegan \& Gordon, 1996), the researchers chose another measure to suit banks' case. They used the number of branches in Portugal as a proxy for bank visibility in customers' eyes. They divided the sample into two groups, large (having a big number of branches) and small (with small number of branches), and expected that the first group will disclose more social information. The result of the study demonstrated the validity of this expectation.

\subsection{Ownership}

Ownership has been pointed out by many researchers to be another influential element in the process of disclosing social and environmental information by corporations. In this regard, ownership of corporation can be seen from its concentration and as a tool reflects its identity (Tagesson et al., 2009). The concentration of ownership has been used by many researchers such as Prencipe (2004), and Cormier (2005), and argued to be influential in disclosure issue, in which a firm with high ownership concentration is more likely to disclose less social and environmental disclosure than that with wide spread shares, and vice versa. Prencipe (2004) added management ownership as another case to cause the same effect, and in the same direction. On the other hand, ownership can be a distinguish standard between governmental firm (shares owned by government) and non-governmental one, and there is a disagreement among researchers pertaining to which kind is disclosing more social and environmental information. A point might worth mentioning in this regard is that, as a firm owned by government is perceived to be owned by all citizens, disclosures made by such firm is more likely to be also different in its content (Tagesson et al., 2009).

Cormier and Gordon (2001) considered ownership structure as one of the determinants of reporting strategies implemented by corporations, since owning corporation publicly will affect that corporation from two angles: 
putting pressure on corporation to provide more information to investors and other interested group, and at the same time, being able, economically, to incur the cost of involving in such process. In a French study, conducted by Cormier and Magnan (2003), ownership (as a component- among others- of information costs) was found to be one of significant determinants of a firm's environmental reporting strategy. Liu and Anbumozhi (2009), emphasised the influence of ownership concentration on the amount of environmental information released by corporations, in which corporation shares possessed by wide range of investors is more likely to be resulted in disclosing more environmental information.

In Canada, the study of Cormier and Gordon (2001) demonstrated the impact of ownership on the extent of social and environmental disclosure made by the three electric companies investigated. The two publicly owned companies were found disclosing more information than the private one. The researchers mentioned to the idea that companies owned by government receive more social and political support, are likely to be more visible, and as a result, politically more sensitive. This was not the case in Italy, where Secchi (2006), found different result, with state-owned companies disclosing less social information than private ones.

Confirming the case of Canada, in another developed country, Sweden, the study of Tagesson et al. (2009) revealed that ownership held by government was proved to be an engine to disclose more social information on websites, whereas private owned companies released less. The researchers highlighted the condition of state-owned companies, which are prone to scrutiny and pressure from government and media regarding their impact on environment and society. They attributed the case of disclosing more social and environmental information by these companies, and its difference from the case of other countries, to national culture in Sweden. They stated "In Sweden there is a long tradition of transparency in the public sector, which is also legally regulated in the principle of public access to official records. This principle gives all Swedish citizens the right to inspect State documents" (Tagesson et al., 2009, p. 361) They proceeded "...Thus, national culture as an explanatory factor is probably needed in order to fully understand disclosure behaviour."'(p. 361).

Conversely, in mixed Singaporean sample (companies operating in: Banking, food and beverages, and hotel), the result of investigating banks case revealed different finding. Tsang (1998) found that Development Bank of Singapore (DBS), which owned mostly by government, released less social information comparing to the other banks. The researcher assumed that well-known companies might feel that there is no need for justifying their existence. The context of the study (socially, politically and other national characteristics) might provide ground for such explanation. In India, the study of Chipalkatti (2002), which focused on disclosures made by 17 Indian banks, downplayed the significance of the relation between the extent of disclosure and the percentage of shares owned by government.

The result was different in the same country, but with bigger sample included 38 banks: 18 public and 20 private. Hossain and Reaz (2007) observed that public banks released more voluntary information than the private ones. This finding was confirmed by another study, which considered the same period (2002-2003), but in another Asian country, Malaysia. Amran and Devi (2008) investigated the influence of government and foreign affiliates, on corporate social disclosure made by 133 companies in Malaysia (in various sectors including banks). The study confirmed the positive impact of Malaysian government (regarding social disclosure) on companies, which most of their shares are owned by government, or dependent on both: government or specifically on governmental contracts. Some probable reasons, for government efforts to promote such disclosure, were provided by the researchers, and those included- inter alia-: creating favourable image for the government, and obtaining economic benefits from attracting international investors who evaluate and appreciate such kind of disclosure. Another confirmation of the positive impact of owning shares by government on the level of voluntary disclosure came from a study conducted in Singapore. Eng and Mak (2003) examined the influence of ownership structure (managerial ownership, block holder ownership and government ownership) on voluntary disclosure made by 158 Singaporean listed firms (financial and non-financial firms) in the year of 1995 . The result of this study demonstrated that increased voluntary disclosure was correlated with significant government ownership in Singaporean firms. As a justification, the researchers claimed that such relation is in line with the arguments that "government ownership increases moral hazard and agency problems, and disclosure is a means of mitigating these problems" (Eng \& Mak, 2003, p. 341).

Moving to another aspect of ownership structure and its influence on voluntary disclosure, interest of foreign investors may lead them to buy shares of national companies, and this is argued to be an action bolsters the trend towards disclosing more information and paying incremental attention to social and environmental ones. Andrew et al. (1989), who considered the case of publicly-listed companies (including banks) in Malaysia and Singapore, proved the significant of firm size in the topic of social disclosure, but they also directed the attention to another dimension. They noted that large companies which disclosed more social information were generally owned by 
foreign investors, and that such case is more likely to be found in developing countries. About two decades later did not bring different result to the study of Haniffa and Cooke (2005). They investigated the annual reports of 139 non-financial firms in Malaysia, in the two years: 1996 and 2002, and found the relationship between social disclosure, made by those firms, and foreign share ownership to be significant. This result reflected, in the researchers' opinion, usage of corporate social disclosure as an attractive tool to guarantee the continuing participation and support of such important shareholders. Haniffa and Cooke (2005) argue that various disclosures might become more desirable, as firm shares were possessed by different investors, especially when foreign ones are a major category. This argument confirms that of Cormier and Maganan (2003) who believe that disseminating environmental information in high level of quality will be the result of holding firm shares by a wide range of investors, with a significant proportion being possessed by foreigners, and as a result, disclosing information in this case can be seen as an action to bridge the gap between managers and those who are geographically far from information source.

Conversely, analysing the annual reports of 17 Indian banks, for the year 2000, by Chipalkatti (2002), resulted in discovering insignificant relationship, between the proportion of shares owned by foreign investors and the level of banks' disclosures. The study of Amran and Devi (2008), also evidenced, in the contrary to the expectations of their study, that foreign shareholders and stakeholders as a whole had no significant effect on corporate social reporting. The researchers justified this result by arguing that such result may occur because of the limited scope of their study. It focused only on annual reports while some companies used other tools (such as stand-alone reports) rather than annual reports to disclose non-financial information. Another possible explanation was provided by Barako and Brown (2008), who got the opposite result to their expectation, which was "The higher the proportion of foreign nationals on the board, the higher the level of voluntary disclosure of corporate social reporting information" (Barako \& Brown, 2008 , p. 315). The researchers argued that the existence of foreigners on bank board may work as a guarantee that the interests of foreign shareholders will be protected, and as a result, this existence might work as a substitution for producing more improved disclosure. Based on this view, foreign ownership (in case of the presence of foreign directors on firm board) can have a negative influence on the level of social and environmental disclosure.

\subsection{Listing on Stock Market}

Listing on stock market is argued to be beneficial to firms. Reints and Vandenburg (1975) pointed that being listed on New York Stock Exchange (NYSE) or the American Stock Exchange (AMEX) is more likely to be associated with a reduction in the risk level of a security. However, the result of some studies did not support this claim. Ying et al. (1977), mentioned to the conflicted results of some studies such as (Furst, 1970; Goulet, 1974; Van, 1970), regarding the positive impact of listing on the market, but they criticised those studies for not making some modifications for the differential risk characteristics of the securities involved. Therefore, the researchers re-examined the impact of listing on market, using a sample of 248 firms listed on New York Stock Exchange or the American Stock Exchange during the period of 1966-1968. Findings revealed that abnormal positive returns were correlated with the listing event.

The amount of information presented in stock market might be the main cause of its efficiency. There are some requirements need to be met so as to register stocks of any firm on the market, and releasing more information is one of those requirements. Moreover, Ying et al. (1977) pointed that firms aiming at listing on a major stock market need not just to meet the market conditions for registering, but also to continue complying with any further requirements, which might be imposed later. As such, applying for registration on such market may be construed as an indicator of managers' confidence in firm's performance. The study of Grant (1980) provided evidences that more information was disclosed (in Wall Street Journal during the years 1960-1964) on 100 listed (NYSE) firms than that on the 100 on the counter (OTC) firms. . He stated "it might be concluded that there is significantly less information available for OTC firms than for the NYSE firms" (Grant, 1980 p. 257). Confirming the benefit of listing on market, Dhaliwal (1983), in examining the case of two samples (OTC firms and the NYSE or AMEX firms), did not find a different result to that of Grant's (1980) study, during the year 1971. This indicated that investors were interested more in listed firms than unlisted ones, and listing on market is correlated with disclosing more information, which is more likely to be resulted in benefiting both firms and investors. The study of Dhaliwal (1983) proved that disclosing more information on listed firms (comparing to non-listed firms) has the potential to reduce the uncertainty pertaining to their financial position, and, as a result, causing a reduction in the cost of equity capital, as investors tend to accept a lower rate of return. Overall, as Saudagaran (1988) mentioned, the increasing number of listed firms nationally and internationally is a proof enough of the perceived usefulness of listing on stock market.

Not just listing on stock market is correlated with disclosing more information, but also the degree of stock 
market seems to be important in affecting the amount of social and environmental information released, since visibility assumed to be influenced accordingly. In Portuguese case, even though Branco and Rodrigues (2008) chose the sample of their study from listed firms, as they are more likely to disclose social information, the researchers found what they described as a "more difficult to explain". They found that, in contrast to the expected, firms in environmentally sensitive sectors did not disclose more environmental information than those which operating in other sectors. Listing on the second market (not main one), which means less visible to investors, has been pointed by the researchers as a potential reason, even partly, for such result.

In another point, listing on more than one stock market, especially foreign stock markets, is argued to be beneficial for both investors and listed companies. Disclosing more information with different aspects (monetary, social and environmental), which assumed to be required by those market, is likely to have a positive impact on the quality of investors' decisions. Hackston and Milne (1996) analysed the annual reports of the largest forty seven companies (including banking sector) listed on the New Zealand Stock Exchange on thirty first December 1992. They divided the sample into four groups; the first included companies listed on: New Zealand, Australia, UK and North America; the second encompassed those which listed on: New Zealand, Australia and UK; the third incorporated New Zealand and Australia; and the last consisted of companies operating only in New Zealand. The results indicated that listing on more than one market abroad may lead to disclosing more information regarding their effect on society. The researchers stated "It may be that dual and multiple overseas listings only have an impact when the countries in which the companies are listed have largely different social reporting requirements" (Hackston \& Milne, 1996, p. 102).

Confirmation of such argument and result came also from different context, a developing country, Haniffa and Cooke (2005) consider a sample of non-financial firms in Malaysia, included 139 firms, and concluded that multiple listing was one of some important factors regarding corporate social disclosure. The researchers indicated that, in the absence of regulations regarding social disclosure in Malaysia, companies operating in Malaysia and listed on foreign stock exchanges took into their account the global concern regarding social issues. This seems to be an important step in order to benefit from the opportunity of listing on other foreign market. This provides such firms with some advantages such as marketing (selling products and services) and relations in conjunction with employees, public and political relations (Biddle \& Saudagaran, 1991; Hossain \& Reaz, 2007; Saudagaran, 1988). Biddle and Saudagaran mentioned accessing to foreign capital as a major benefit.

However, some studies did not confirm the positive impact of multiple exchanges listing on voluntary disclosure. Hossain and Reaz (2007), in considering voluntary disclosure made by 38 listed Indian banks in the year of 2002-2003, hypothesized the existence of a positive association between listing with multiple stock exchanges and the amount of information disclosed voluntarily. The result of their analysis revealed insignificance of multiple exchanges listing in relation to the extent of voluntary disclosure, i.e. the level of such disclosure did not rely on the number of stock market banks listed on. An explanation of such result can be found in the studies of some researchers such as Haniffa and Cooke (2005) and Nier and Baumann (2006). Haniffa and Cooke (2005) pointed out to the differences between listing in developing countries and that in developed ones, as in the case of less developed countries there is an absence or a lack of rules and regulations regarding social disclosures, as well as low level (or absence) of public awareness pertaining to such issue, while the position is opposite in more developed countries. As such, firms listed in developing nations are likely to disclose less social information comparing to firms listed in developed nations owning to different rules, regulations, and public awareness, which are expected to be existed and more advanced in latter context. Moreover, even among developed countries, listing in more developed ones is likely to positively influence the extent and quality of disclosures made by listed firms, since potentially there are more other requirements. In the study of Nier and Baumann (2006), who analysed a sample of 729 listed banks in 32 different countries over the years 1993 to 2000, it was found- inter alia- that banks with lower realised risk were those which disclosed more information in their reports or by having a second listing in the US ( which assumed to be more developed and demanding for more information). The authors stated "Both the quality and the quantity of disclosure a bank provides may depend on where it is listed" (Nier \& Baumann, 2006 , p. 337). Going back to the result of Hossain and Reaz (2007), the two stock market (the Bombay Stock Exchange (BSE) and the National Stock Exchange (NSE)), on which Indian banks were listed, are located both in India, which means the same political, social, and economic context. As such, the result (that the extent of voluntary disclosure does not related to how many stock exchange, banks listed on) can be understood. Additional confirmation (in the context of developing countries) can be found in study of Leutz and Verrecchia (2000), which showed that lower measures of information asymmetry and higher stock liquidity were found in the case of German firms which implemented US GAAP in their reports, comparing to German firms which applied local guidelines. 
What is assumed to be proved above is that listing on stock exchange (and how many market and where) entails firms to disclose more information to meet the requirements set in such market, and satisfy investors need of adequate and suitable information for making informed decisions.

\section{Corporate Governance}

In addition to the previous factors, influencing the existence and extent of CSED, there is another major set of factors, included in term "corporate governance". Some definitions have been provided for this term, such as "the process by which corporations are made responsive to the rights and wishes of stakeholders" (Demb \& Neubauer, 1992), "the manner in which companies are controlled and in which those responsible for the direction of companies are accountable to the stakeholders of these companies"(Dahya, Lonie, \& Power, 1996, p. 71), and "the system by which companies are directed and controlled" (Cadbury \& Books24x, 2002).

It can be noted from those definitions that corporate governance is a detailed system by which firms are controlled, in a way leads to accomplishing firms' and their stakeholders' goals. Such system influences all procedures conducted within firms, and as a result, it is reasonable to expect that such system is also affecting the communication process between firms and all interested groups in society. Thus, since CSED has become a major channel of expressing firms' attitudes towards issues of society and environment, it is logical to argue that CSED is affected by corporate governance. Gibbins et al. (1990) argue that it is vital to consider corporate governance in order to understand the process of information disclosure.

The following are factors representing some aspects of corporate governance and their influences on CSED.

\subsection{Chairman of the Board with Multiple Directorships}

It is possible that the chairman of the board has more influence, than other members of the board, on firm's policy and its decisions regarding various matters, internally and externally, and as such CSED is not likely to be an exception (Haniffa \& Cooke, 2005). Being a member of two boards or more is likely to be associated with extending knowledge and experiences of that person in regard to similar issues face firms in business world, the matter which in turn would positively impact upon his ability and performance. As such, since social and environmental disclosure has recently become a hot topic, the participation of the chairman in discussions regarding such disclosure in different firms (which he is also a member in their board), is expected to add to his knowledge and experience, and to have a positive impact on his participation in similar discussions, in the firm which he is the chairman of its board. Zahra and Stanton (1988) indicated that chairman may emphasise the importance of disclosing information regarding some issues, based on his experience in other companies, where he participated as a member of their boards.

From another angle, Dimaggio and Powell (1983) hypothesized "The more uncertain the relationship between means and ends the greater the extent to which an organization will model itself after organizations it perceives to be successful" (DiMaggio \& Powell, 1983, p. 154), and "The more ambiguous the goals of an organization, the greater the extent to which the organization will model itself after organizations that it perceives to be successful." (DiMaggio \& Powell, 1983 , p. 155). As such, since social and environmental disclosure is still voluntary in many countries, many firms, in case of its lack of awareness and knowledge concerning such matter, try just to imitate what others do in that regard, and in this case, the existence of a chairman with multiple directorships is more likely to be helpful in this issue. Imitation behaviour of managers has been proved by Haunschild (1993), who found that firm managers imitate the acquisition activities of other firms, which those managers were also members in their board.

Consequently, due to multiple participation in firms' boards, changes in strategies and policies of some firms will be a motivation for similar changes in other firms (Bettenhausen \& Murnighan, 1985; Haniffa \& Cooke, 2005; Haunschild, 1993). Thus, based on this, it seems that there is a benefit circle between firms' boards, intentionally or unintentionally, turning firms from being competitors to become co-operators.

In examining empirically the impact of multiple directorship on social disclosure, Haniffa and Cooke (2005, p. 400) stated "We have not come across any literature that directly discusses multiple directorships. However, it has been discussed, indirectly, under directorship interlocks." The researchers hypothesized that "Ceteris paribus, the extent of CSD is greater for companies with a chairman having multiple directorships". Analysing the annual reports of 139 non-financial Malaysian companies in the two years 1996 and 2002, proved the validity of this hypothesis, by demonstrating- inter alia- a significant relationship between Chairs with multiple directorships and disclosing social information regarding companies' activities. 


\subsection{Non-Executive Directors on the Board}

According to agency theory, behaviours of firm's directors are needed to be monitored and controlled by firm board, in order to prevent any inappropriate action not serving firm interests (Jensen \& Meckling, 1976). Firm board consists of executive and non-executive directors, and it might be seen as a useless task to implement the process of monitors and control by those who have executive roles in firm activities. Many researchers argued that outside directors are objective and independent (Eugene F. Fama, 1980; Kosnik, 1987; Mizruchi, 1983; Singh \& Harianto, 1989). Mangel and Singh (1993) stated "the outside members are theoretically in a position to resist influence from the CEO and other inside directors" (Mangel \& Singh, 1993, p. 342).

Monitoring management is one of the duties of outside directors (Franks, Mayer, \& Renneboog, 2001), believed to be played better by them more than insider directors (Weisbach, 1988). Having outside directors in the board rises the chance of protecting interests of stakeholders against possible emergence of opportunist behaviour of top management (E.F. Fama \& Jensen, 1983). Brickley and James (1987), investigating the case of banks, found that outsider directors may serve as an effective tool of control on managerial consumption of perquisites. Evaluating the performance of managers, and replacing unsuccessful ones, is an important role of the board of directors, and this task has a big chance to be accomplished in case of a board dominated by outside directors (Weisbach, 1988).

According to Pearce and Zahra (1991), board dominated by outside directors is a condition of the existence of proactive board. They listed the aims and the usefulness of inclusion of such kind of directors as the following "to enhance their independence of management, to increase the level of expertise presented among directors, to enhance objectivity in board proceedings and decisions, and to ensure the effective representation of important constituents in society" (Pearce \& Zahra, 1991, p. 137). The desire of becoming successful, in accomplishing such goals, has been emphasised to be a motive for outside directors to have a positive role in the firms' boards. Fama and Jensen (1983, p. 315) stated "Outside directors have incentives to develop reputations as experts in decision control ... The value of their human capital depends primarily on their performance as internal decision managers in other organizations". Non-executive directors in firms with poor performance are prone to lose reputation, and have a little chance to be again considered for getting such high position in future (Gilson, 1990; Kaplan \& Reishus, 1990). As a result, Outside directors of a firm are motivated to do their best to ensure the success of that firm, because a successful firm is a sign of the capability of its directors (Weisbach, 1988). Such motivation logically leads to the assumption that non-executive directors should be interested in issues that linked the firm to society and environment. Zahra and Stanton (1988) claimed the likelihood that non-executives are responsive in regarding to issues of honour and obligations, and as a result, they are inclined to encourage fulfilling corporate responsibility towards society. Based on such arguments, corporate decisions, concerning social and environmental issues, are more likely to be positively affected by boards dominated by non-executive directors.

Nevertheless, a doubt can be casted on the objectivity of non-executive directors. There is an argument that since non-executive directors in a firm are corporate executive officers in other firms, it is possible that they may be sympathetic to corporate executive officers in the company in question, the matter which might influence the objectivity claimed (Mangel \& Singh, 1993 ). Moreover, the imitation behaviour conducted by firms (Bettenhausen \& Murnighan, 1985; Dennis Cormier \& Michel Magnan, 2003; DiMaggio \& Powell, 1983; Haniffa \& Cooke, 2005; Haunschild, 1993) can downplay the perceived positive impact of non-executive directors, if such directors came from other firms which do not pay attention to social and environmental matters, or in the case an ignorance of such issue was the general trend of the whole industry.

Another important notice has been highlighted by Franks et al. (2001), who posed the following question: Who Disciplines Management in Poorly Performing Companies? The researchers considered five groups as a possible answer, and non-executive directors were one of them. Taking into account the two main functions of non-executive directors, which are: a monitoring and advisory, the researchers found that, unlike the case in the United States, ( see Hermalin \& Weisbach, 1991) non-executive directors in the United Kingdom do not perform a disciplinary function. The possibility that non-executive directors may replace managers, in case of bad performance, has been examined and it was found that conversely no proof of disciplining implemented by non-executive directors. Instead, the negative relationship between the proportion of nonexecutives and board turnover has been found. The researchers blamed UK regulations which did not pay enough attention to fiduciary responsibilities of directors "Weak fiduciary obligations on directors have resulted in nonexecutives playing more of an advisory than a disciplinary role" (Franks et al., 2001, p. 246). As a comparison, the authors mentioned the opposite case, in the United States, where directors have fiduciary responsibility towards shareholders, and failing to incur such responsibilities might result in prosecution against the directors (as proved 
by Millstein \& MacAvoy, 1998). This matter has led to an increase in the proportion of non-executive directors in directors' boards, and resulted in governance function becoming more active.

In addition to the above, low level of qualification and experience of non-executive directors may prevent creation and improvement of the awareness towards social responsibility of firms. In the study of Haniffa and Cooke (2005), insignificant relationship was found between corporate social responsibility and the existence of non-executive directors on boards of a sample of 139 non- financial companies, operating in Malaysia within the years of 1996 and 2002. The researchers interpreted such finding by mentioning to two causes: inadequate levels of knowledge and experience of non-executive directors, and indifference towards social issues.

Another point should be mentioned here is the substitution relation between voluntary disclosure and the existence of non-executive directors, which has been presented, by some researchers, as an explanatory reason of the low level of disclosure. Eng and Mak (2003) tested the relation between independent directors and voluntary disclosure of 158 Singaporean listed firms (financial and non-financial firms) in the year of 1995. The researchers found that there is a negative association between the number of outside directors on the board and voluntary disclosure made by Singaporean firms. That is, the more outside directors, the higher level of independency of firm board, and as a result, the less disclosing voluntary information. Eng and Mak admitted that this result is inconsistent with that of prior studies, but they justified such contrast by claiming the existence of a substitute relationship between the two variables, in the monitor process of managers' behaviour.

In banks case, Hossain and Reaz (2007) hypothesized that "There is a positive association between the proportion of non-executive directors on the board and the extent of voluntary disclosure of information". The result was opposite to the predicted direction. It was found that board composition was not an important factor in interpreting the level of voluntary disclosure made by thirty eight Indian banks in the year of 2002-2003. The researchers justified this finding by saying "independent directors cannot provide any pressure to provide voluntary information. Moreover, the bank's financial information also plays a vital role in day to day economic activities. The bank follows the mandatory instruction strictly and independent directors also keep pressure on it" (Hossain \& Reaz, 2007 , p. 284). Such explanation seems incomplete and, in somehow, misleading if the results were to be accepted in general without reasonable justification. There is no explicit reason why non-executive directors could not put pressure on banks to disclose voluntary information. The claim that banks follow the mandatory instruction strictly did not offer any justification for the result that those banks disclose "a considerable amount of voluntary disclosure" and "corporate social disclosure... has been disclosed in the annual reports in the Indian banks to an acceptable level" (Hossain \& Reaz, 2007, p. 285). The researchers provided just two elements (size and assets- in- pace) to be related to this acceptable level, and rejected the impacts of any other element such as: board composition, diversification, age, multiple exchange listing and complexity of business. Furthermore, no external factors such as: cultural, political or economic effects have been investigated so as to explain the level of voluntary disclosure found, and to justify why such elements did not work.

The positive relation, claimed at the beginning of this discussion, has been proved by many studies. Chen and Jaggi (2000) examined the relationship between non-executive directors on corporate boards and comprehensive financial disclosures, made by eighty seven large Hong Kong firms in 1993 and 1994. Findings indicated a positive relationship between the two variables. However, this relation tend to be weaker for family-controlled firms. The study proved that the existence of non- executive directors in the firm board encourages firms to comply with disclosure requirements, enhances monitoring process, and increases transparency level within the board. Such changes are more likely to be resulted in enhancement in the comprehensiveness and quality of disclosures (Forker, 1992).

In banking sector, Barako and Brown (2008), in their study of annual reports of forty Kenyan banks, confirmed the significance of the existence of non-executive directors on bank board in enhancing social disclosure practices. It was found that, the more non-executive directors on bank board, the more improvement achieved in social disclosure. This was a result of reform policy implemented by the central bank in Kenya, which encouraged Kenyan banks to include their boards more non- executive directors. A confirmation of this study came from the case of Bangladeshi banks, which were studied by Khan (2010). The researcher used the multiple regressions to gauge the impact of three elements of corporate governance, including non-executive directors on bank board, on corporate social responsibility reporting. Significant impact was found regarding the factor mentioned.

\subsection{Foreigners on Bank Board}

In line with the arguments that ownership of foreigners has an impact on the level and quality of social and 
environmental information released by firms, some researchers argue also that corporate social and environmental disclosure can be affected by the existence of foreign nationals in board of directors. Of course, foreign nationals, in this context, are assumed to be those who are from developed countries, where social and environmental issues receive a considerable amount of attention from information users and society at large. It is assumed that such interest, and knowledge, will be transferred to boards of domestic firms in developing countries, by the foreigners, either: executive or non-executive directors.

One of the hypotheses of Khan's (2010) study was that the degree of corporate social disclosure, made by Bangladesh banks, is associated positively with the proportion of foreign nationals on bank's board. This proportion was around twenty one per cent overall, and in some banks, represented half of the banks' boards. The results of the study proved the validity of the hypothesis mentioned, i.e. the level of voluntary social disclosure of Bangladesh banks was found to be significantly correlated with the proportion of foreign nationals on the board.

In contrast, the case of Kenyan banks showed reverse relation. Barako and Brown (2008) found that there was insignificant association, between the proportion of foreign national on bank board and the level of corporate social reporting made by Kenyan banks. Barako and Brown justify their finding by assuming that, since the existence of foreign nationals on bank's board is likely to be seen as a protection of interests of foreign owners, presence of foreign directors downplays the importance of social disclosure. In other words, a substitution relationship may be existed, between social disclosure and foreign directors on bank's board.

Such explanation seems to be inconsistent with the common assumption that foreign nationals represent high levels of Knowledge and care about environment and society. Other alternative explanations can be provided here to justify such result. First, the proportion of foreign nationals on the board might be small, and as a result, insignificant and non-influential in decision making process regarding social and environmental disclosure. Second, the issues of whether the foreigners on the bank board were: executive or non-executive directors, qualified or not qualified, with or without multiple directorships, may play an explanatory role in this matter. Third, such result might be justified also by looking at Kenyan context. The quality of legal system and the political situation and the level of corruption (which is widespread in many African countries) might spoil the expected result. That is, such possible circumstances may alter the meaning of interest to be confined to just financial interest of the bank owners, irrespective of how much damage might happen to Kenyan society and its environment. in other words, being aware of the weakness of legal and punishments system in regard to the issue of negative impacts of banks' activities on environment and society, foreign investors and directors may be motivated to ignore, or at least not encourage, fulfilling the responsibility of banks towards environment and society.

\section{Conclusion}

In this paper, the importance of corporate characteristics and internal contextual factors (represented in corporate governance) has been discussed and highlighted in terms of their relationship with the issue of disclosure, specifically corporate social and environmental disclosure. The variables chosen and discussed here are just some of many other influential variable, which include, and not limited to, industry membership, corporate age, length of management decision horizon, presence of a corporate social reporting committee, and attitudes of managers (Adams, 2002). Studies aiming to investigate and understand the attitude of banks towards the issue of social and environmental disclosure, should take these factors into account. Lastly, it might be worth mentioning to emphasize that understanding the impact of these factors within the political and social context of the country, where the phenomenon is studied, is another essential matter. In the introduction of this paper, it was mentioned that the factors influencing managers' decisions regarding disclosure issue include general contextual factors. The relationship between these factors and those discussed here can offer a justification for some unexpected results of some related studies, and as such should not be ignored.

\section{References}

Adams, C. A. (2002). Internal organisational factors influencing corporate social and ethical reporting: Beyond current theorising. Accounting, Auditing \& Accountability Journal, 15(2), 223. http://dx.doi.org/10.1108/09513570210418905

Ahmed, K., \& Nicholls, D. (1994). The impact of non-financial company characteristics on mandatory compliance in developing countries: The case of Bangladesh. The International Journal of Accounting, 29(1), 60-77.

Amran, A., \& Devi, S. S. (2008). The impact of government and foreign affiliate influence on corporate social 
reporting: The case of Malaysia. Managerial Auditing Journal, 23(4), 386-404. http://dx.doi.org/10.1108/02686900810864327

Andrew, B. H., Gul, F. A., Guthrie, J. E., \& Teoh, H. Y. (1989). A note on corporate social disclosure practices in developing countries: The case of Malaysia and Singapore. The British Accounting Review, 21(4), 371-376. http://dx.doi.org/10.1016/0890-8389(89)90034-6

Barako, D. G., \& Brown, A. M. (2008). Corporate Social Reporting and Board Representation: Evidence from the Kenyan Banking Sector. Journal of Management and Governance, 12(4), 309-324. http://dx.doi.org/10.1007/s10997-008-9053-x

Bettenhausen, K., \& Murnighan, J. K. (1985). The Emergence of Norms in Competitive Decision-Making Groups. Administrative Science Quarterly, 30(3), 350-372.

Biddle, G. C., \& Saudagaran, S. M. (1991). Foreign Stock Listings: Benefits, Costs, and the Accounting Policy Dilemma. Accounting Horizons, 5(3), 69-80.

Branco, M. C., \& Rodrigues, L. L. (2006). Communication of corporate social responsibility by Portuguese banks: A legitimacy theory perspective. Corporate Communications: An International Journal, 11(3), 232-248. http://dx.doi.org/10.1108/13563280610680821

Branco, M., \& Rodrigues, L. (2008). Factors Influencing Social Responsibility Disclosure by Portuguese Companies (vol. 83, pp. 685-701). Springer Science \& Business Media B.V. http://dx.doi.org/10.1007/s10551-007-9658-z

Brickley, J. A., \& James, C. M. (1987). The takeover market, corporate board composition, and ownership structure: The case of banking. Journal of Law and Economics, 161-180.

Cadbury, A. S., \& Books, I. (2002). Corporate governance and chairmanship: a personal view. New York: Oxford University Press.

Chen, C. J. P., \& Jaggi, B. (2000). Association between independent non-executive directors, family control and financial disclosures in Hong Kong. Journal of Accounting and Public Policy, 19(4-5), 285-310. http://dx.doi.org/10.1016/s0278-4254(00)00015-6

Chipalkatti, N. (2002). Market microstructure effects of the transparency of Indian banks. National Stock Exchange, India Working Paper.

Clarke, J., \& Gibson Sweet, M. (1999). The use of corporate social disclosures in the management of reputation and legitimacy: a cross sectoral analysis of UK Top 100 Companies. Business Ethics: A European Review, 8(1), 5-13. http://dx.doi.org/10.1111/1467-8608.00120

Cooke, T. E. (1991). An assessment of voluntary disclosure in the annual reports of Japanese corporations. International Journal of Accounting, 26, 174-189.

Cormier, D., \& Gordon, I. M. (2001). An examination of social and environmental reporting strategies. Accounting, Auditing \& Accountability Journal, 14(5), 587-617. http://dx.doi.org/10.1108/EUM0000000006264

Cormier, D., \& Magnan, M. (1999). Corporate Environmental Disclosure Strategies: Determinants, Costs and Benefits. Journal of Accounting, Auditing and Finance, 14(4), 429-451.

Cormier, D., \& Magnan, M. (2003). Does disclosure matter? CA Magazine, 136(4), 43.

Cormier, D., \& Magnan, M. (2003). Environmental reporting management: a continental European perspective. Journal of Accounting and Public Policy, 22(1), 43-62. http://dx.doi.org/10.1016/s0278-4254(02)00085-6

Cormier, D., Ledoux, M. J., \& Magnan, M. (2011). The informational contribution of social and environmental disclosures for investors. Management Decision, 49(8), 1276-1304. http://dx.doi.org/10.1108/00251741111163124

Cormier, D., Magnan, M., \& Van Velthoven, B. (2005). Environmental disclosure quality in large German companies: Economic incentives, public pressures or institutional conditions? European Accounting Review, 14(1), 3-39. http://dx.doi.org/10.1080/0963818042000339617

Cowen, S. S., Ferreri, L. B., \& Parker, L. D. (1987). The impact of corporate characteristics on social responsibility disclosure: A typology and frequency-based analysis. Accounting, Organizations and Society, 12(2), 111-122. http://dx.doi.org/10.1016/0361-3682(87)90001-8

Dahya, J., Lonie, A. A., \& Power, D. M. (1996). The Case for Separating the Roles of Chairman and CEO: An 
Analysis of Stock Market and Accounting Data. Corporate Governance: An International Review, 4(2), 71-77. http://dx.doi.org/10.1111/j.1467-8683.1996.tb00136.x

Deegan, C., \& Gordon, B. (1996). A Study of the Environmental Disclosure Practices of Australian Corporations. Accounting \& Business Research, 26(3), 187-199.

Demb, A., \& Neubauer, F. F. (1992). The corporate board: confronting the paradoxes. Long range planning, 25(3), 9-20. http://dx.doi.org/10.1016/0024-6301(92)90364-8

Dhaliwal, D. (1983). Exchange-listing effects on a firm's cost of equity capital. Journal of Business Research, 11(2), 139-151. http://dx.doi.org/ 10.1016/0148-2963(83)90023-1

DiMaggio, P. J., \& Powell, W. W. (1983). The Iron Cage Revisited: Institutional Isomorphism and Collective Rationality in Organizational Fields. American Sociological Review, 48(2), 147-160. http://dx.doi.org/10.1016/S0742-3322(00)17011-1

Eng, L. L., \& Mak, Y. T. (2003). Corporate governance and voluntary disclosure. Journal of Accounting and Public Policy, 22(4), 325-345. http://dx.doi.org/10.1016/s0278-4254(03)00037-1

Fama, E. F. (1980). Agency Problems and the Theory of the Firm. Journal of Political Economy, 88(2), 288-307.

Fama, E. F., \& Jensen, M. C. (1983). Agency problems and residual claims. JL \& Econ., 26, 327.

Farook, S. Z., Lanis, R., \& Hassan, K. M. (2011). Determinants of Corporate Social Responsibility Disclosure: The Case of Islamic Banks. SSRN eLibrary. http://dx.doi.org/10.2139/ssrn.1828624

Forker, J. J. (1992). Corporate Governance and Disclosure Quality. Accounting \& Business Research, 22(86), 111-124. http://dx.doi.org/10.1080/00014788.1992.9729426

Franks, J., Mayer, C., \& Renneboog, L. (2001). Who Disciplines Management in Poorly Performing Companies? Journal of Financial Intermediation, 10(3-4), 209-248. http://dx.doi.org/10.1006/jfin.2001.0317

Furst, R. W. (1970). Does Listing Increase the Market Price of Common Stocks? Journal of Business, 43(2), $174-180$.

Gao, S. S., Heravi, S., \& Xiao, J. Z. (2005). Determinants of corporate social and environmental reporting in Hong Kong: a research note. Accounting Forum, 29(2), 233-242. http://dx.doi.org/10.1016/j.accfor.2005.01.002

Gibbins, M., Richardson, A., \& Waterhouse, J. (1990). The Management of Corporate Financial Disclosure: Opportunism, Ritualism, Policies, and Processes. Journal of Accounting Research, 28(1), 121-143.

Gilson, S. C. (1990). Bankruptcy, boards, banks, and blockholders: Evidence on changes in corporate ownership and control when firms default. Journal of Financial Economics, 27(2), 355-387. http://dx.doi.org/10.1016/0304-405x(90)90060-d

Goulet, W. M. (1974). Price changes, managerial actions and insider trading at the time of listing. Financial Management (pre-1986), 3(1), 30-36.

Grant, E. B. (1980). Market Implications of Differential Amounts of Interim Information. Journal of Accounting Research, 18(1), 255-268.

Hackston, D., \& Milne, M. J. (1996). Some determinants of social and environmental disclosures in New Zealand companies. Accounting, Auditing \& Accountability Journal, 9(1), 77. http://dx.doi.org/10.1108/09513579610109987

Haniffa, R. M., \& Cooke, T. E. (2005). The impact of culture and governance on corporate social reporting. Journal of Accounting and Public Policy, 24(5), 391-430. http://dx.doi.org/10.1016/j.jaccpubpol.2005.06.001

Haunschild, P. R. (1993). Interorganizational Imitation: The Impact of Interlocks on Corporate Acquisition Activity. Administrative Science Quarterly, 38(4), 564-592.

Hermalin, B. E., \& Weisbach, M. S. (1991). The Effects of Board Composition and Direct Incentives on Firm Performance. Financial Management, 20(4), 101-112.

Hossain, M., \& Hammami, H. (2009). Voluntary disclosure in the annual reports of an emerging country: The case of Qatar. Advances in Accounting, 25(2), 255-265. http://dx.doi.org/10.1016/j.adiac.2009.08.002

Hossain, M., \& Reaz, M. (2007). The determinants and characteristics of voluntary disclosure by Indian banking companies. Corporate Social Responsibility and Environmental Management, 14(5), 274-288. 
http://dx.doi.org/10.1002/csr.154

Imam, S. (2000). Corporate social performance reporting in Bangladesh. Managerial Auditing Journal, 15(3), 133-142. http://dx.doi.org/10.1108/02686900010319384

Jensen, M. C., \& Meckling, W. H. (1976). Theory of the firm: Managerial behavior, agency costs and ownership structure. Journal of Financial Economics, 3(4), 305-360. http://dx.doi.org/10.1016/0304-405x(76)90026-x

Kahl, A., \& Belkaoui, A. (1981). Bank annual report disclosure adequacy internationally. Accounting and Business Research, 11(43), 189-196. http://dx.doi.org/10.1080/00014788.1981.9729700

Kaplan, S. N., \& Reishus, D. (1990). Outside directorships and corporate performance. Journal of Financial Economics, 27(2), 389-410. http://dx.doi.org/10.1016/0304-405x(90)90061-4

Khan, M. H. U. Z. (2010). The effect of corporate governance elements on corporate social responsibility (CSR) reporting: Empirical evidence from private commercial banks of Bangladesh. International Journal of Law and Management, 52(2), 82-109. http://dx.doi.org/10.1108/17542431011029406

Kosnik, R. D. (1987). Greenmail: A Study of Board Performance in Corporate Governance. Administrative Science Quarterly, 32(2), 163-185.

Lang, M., \& Lundholm, R. (1993). Cross-Sectional Determinants of Analyst Ratings of Corporate Disclosures. Journal of Accounting Research, 31(2), 246-271.

Leuz, C., \& Verrecchia, R. E. (2000). The economic consequences of increased disclosure. Journal of Accounting Research, 38, 91-124. http://dx.doi.org/10.1016/j.jfineco.2005.06.002

Liu, X., \& Anbumozhi, V. (2009). Determinant factors of corporate environmental information disclosure: an empirical study of Chinese listed companies. Journal of Cleaner Production, 17(6), 593-600. http://dx.doi.org/ 10.1016/j.jclepro.2008.10.001

Mangel, R., \& Singh, H. (1993). Ownership Structure, Board Relationships and CEO Compensation in Large US Corporations. Accounting \& Business Research, 23(91A), 339-350. http://dx.doi.org/10.1080/00014788.1993.9729902

Mangos, N. C., \& Lewis, N. R. (1995). A socio-economic paradigm for analysing managers' accounting choice of behaviour. Accounting, Auditing \& Accountability Journal, $8(1), \quad 38$. http://dx.doi.org/10.1108/09513579510079117

McKinnon, J. L., \& Dalimunthe, L. (1993). Voluntary disclosure of segment information by Australian $\begin{array}{lllll}\text { diversified } & \text { companies. } & \text { Accounting }\end{array}$ http://dx.doi.org/10.1111/j.1467-629X.1993.tb00192.x

Millstein, I. M., \& MacAvoy, P. W. (1998). The Active Board of Directors and Performance of the Large Publicly Traded Corporation. Columbia Law Review, 98(5), 1283-1322.

Mizruchi, M. S. (1983). Who Controls Whom? An Examination of the Relation Between Management and Boards of Directors in Large American Corporations. Academy of Management Review, 8(3), 426-435. http://dx.doi.org/ 10.5465/amr.1983.4284426

Nier, E., \& Baumann, U. (2006). Market discipline, disclosure and moral hazard in banking. Journal of Financial Intermediation, 15(3), 332-361. http://dx.doi.org/10.1016/j.jfi.2006.03.001

Patten, D. M. (1991). Exposure, legitimacy, and social disclosure. Journal of Accounting and Public Policy, 10(4), 297-308. http://dx.doi.org/10.1016/0278-4254(91)90003-3

Pearce, J. A., \& Zahra, S. A. (1991). The relative power of ceos and boards of directors: Associations with

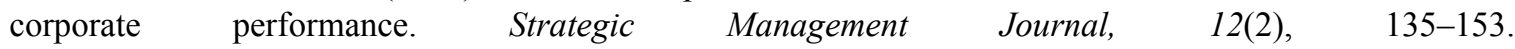
http://dx.doi.org/10.1002/smj.4250120205

Prencipe, A. (2004). Proprietary costs and determinants of voluntary segment disclosure: evidence from Italian listed companies. European Accounting Review, 13(2), 319-340. http://dx.doi.org/10.10800963818042000204742

Reints, W. W., \& Vandenberg, P. A. (1975). The Impact of Changes in Trading Location on a Security's Systematic Risk. Journal of Financial and Quantitative Analysis, 10(5), 881-890. http://dx.doi.org/10.2307/2330279

Saudagaran, S. M. (1988). An empirical study of selected factors influencing the decision to list on foreign stock exchanges. Journal of International Business 
http://dx.doi.org/10.1057/palgrave.jibs. 8490377

Secchi, D. (2006). The Italian experience in social reporting: an empirical analysis. Corporate Social Responsibility and Environmental Management, 13(3), 135-149. http://dx.doi.org/10.1002/csr.96

Singh, H., \& Harianto, F. (1989). Management-Board Relationships, Takeover Risk, and the Adoption of Golden Parachutes. Academy of Management Journal, 32(1), 7-24. http://dx.doi.org/10.2307/256417

Singhvi, S. S. D., \& Harsha B. (1971). An empirical analysis of the quality of corporate financial disclosure. Accounting Review, 46(1), 129-138.

Tagesson, T., Blank, V., Broberg, P., \& Collin, S. O. (2009). What explains the extent and content of social and environmental disclosures on corporate websites: a study of social and environmental reporting in Swedish listed corporations. Corporate Social Responsibility \& Environmental Management, 16(6), 352-364. http://dx.doi.org/ 10.1002/csr.194

Tsang, E. W. K. (1998). A longitudinal study of corporate social reporting in Singapore: the case of the banking, food and beverages and hotel industries. Accounting, Auditing \& Accountability Journal, 11(5), 624-635. http://dx.doi.org/10.1108/09513579810239873

Van, H. J. C. (1970). New listings and their price behavior. Journal of Finance, 25(4), 783-794. http://dx.doi.org/10.1111/j.1540-6261.1970.tb00552.x

Wallace, R. S. O., \& Naser, K. (1995). Firm-specific determinants of the comprehensiveness of mandatory disclosure in the corporate annual reports of firms listed on the stock exchange of Hong Kong. Journal of Accounting and Public Policy, 14(4), 311-368. http://dx.doi.org/10.1016/0278-4254(95)00042-9

Watts, R. L, \& Zimmerman, J. L. (1978). Towards a Positive Theory of the Determination of Accounting Standards. Accounting Review, 53(1), 112-134.

Weisbach, M. S. (1988). Outside directors and CEO turnover. Journal of Financial Economics, 20, 431-460. http://dx.doi.org/10.1016/0304-405X(88)90053-0

Ying, L. K. W., Lewellen, W. G., Schlarbaum, G. G., \& Lease, R. C. (1977). Stock Exchange Listings and Securities Returns. The Journal of Financial and Quantitative Analysis, 12(3), 415-432. http://dx.doi.org/10.2307/2330543

Zahra, S. A., \& Stanton, W. W. (1988). The implications of Board of Directors' composition on corporate strategy and performance. International Journal of Management, 5(2), 229-236.

\section{Copyrights}

Copyright for this article is retained by the author(s), with first publication rights granted to the journal.

This is an open-access article distributed under the terms and conditions of the Creative Commons Attribution license (http://creativecommons.org/licenses/by/3.0/). 